\title{
Developing Spiritual Education: Solutions to Realize People Winning in the Free Market Era
}

\author{
D Hartono \\ IAI Al-Khoziny Sidoarjo, Indonesia \\ Email: djoko hartono70@yahoo.co.id
}

\begin{abstract}
This research aims to find out ways and methods that can be done so that the spiritual development of education can be a solution to realize Indonesian society ready to compete in the free market era. This type of research is library research or library research that is designed through a qualitative approach using descriptive methods. Researchers as the main instrument in critically and in-depth study of relevant library materials. The results of the study pointed to $\mathrm{k}$ 's spiritual development can be used as a solution in creating a society ready to compete in a free market .
\end{abstract}

Keywords: spiritual education; and the free market

\section{INTRODUCTION}

Education is basically a major factor in people's lives. Every element in community life proceeds through an education [1]. The process of education and learning indicated in the holy book of the Koran, took place before Allah sent Adam down as the first human being on earth. The education does not only involve material / worldly knowledge but also the nature of monotheism (spiritual) or vice versa simultaneously [2-5].

The process of integrating spiritual values and profane things in education continues to be perpetuated by the Prophets and Apostles of Allah and humanity who are followers, from Adam as the first Prophet to the close of Rasulullah Muhammad SAW who became God's chosen figure to be an agent of social change until this time. Provision of the education and learning process is certainly as a medium to organize and realize the community in order to have a culture, and an established civilization in the midst of this profane material nature. Thus it becomes clear to us that Islam in paying attention to education really provides a very balanced, crucial and serious portion [2-5].

Education for a nation, actually plays a very dominant in determining the fate of the nation in the future a right to come. For this reason, the state and the government regulate all matters relating to education through the 1945 Constitution article 31, Law No.2 of 1998, and / Law No.20 of 2003 concerning the National Education System.

Especially at this time our society is faced with the life of the free market era as the impact of globalization. The global world is significantly expanding and making the competitive environment increasingly complex. The free market that has a big influence on all aspects of life (including the world of education) must be responded intelligently by education stakeholders in Indonesia as quickly as possible and programmed to make changes and development and innovation. This is because the world of education is actually the spearhead for making changes in society and nation. 
Education which is a need for the community and the nation should immediately make changes and development. One intended development is to develop a spiritual education that is immediately conveyed in the learning process in every existing educational institution

Developing true spiritual education is absolutely needed to be implemented in the process of education and learning in Indonesian society as an effort to prepare them to be ready to compete physically and mentally if they want to continue to exist and gain excellence and victory.

Some research shows that from thirty favorite headmasters who successfully lead educational organizations / institutions in Surabaya, they are spiritualists [6]. The success of noble industry organizations (developing a dual mission: profit and social) is not enough to only be supported by reliable capital and human capital but spiritual leadership is also needed. This spiritual leadership can create an effective noble industry, namely a conducive organizational culture, effective organizational processes and innovations in the organization. Spiritual leadership is proven to develop the organization [7]. Spiritual apparently also has a positive effect on employee performance in a company [8].

Thus, research to find out ways or methods that can be done so that the spiritual development of education can be a solution to realize Indonesian society ready to compete in the free market era needs to be done.

\section{METHOD}

This type of research is the research library or library research that is designed through a qualitative approach with descriptive method. The researcher is a key instrument to collect data and examine critically and in-depth on relevant library materials. Data is collected through four stages, namely: data reduction, data presentation, inference and verification, and final conclusions. Data analysis was carried out with content analysis, functional analysis and critical analysis. The research findings were tested for validity through consultation with supervisors and expert experts, and peer examinations through discussion.

\section{RESULT AND DISCUSSION}

A. Spiritual development can be used as a solution in realizing a society ready to compete in the free market era .

The findings in this study develop the theories put forward by existing education experts as follows:

Cristopher J Lucas as quoted by A. Malik Fajar in this regard stated that education holds an extraordinary reality to create all aspects of the environment and can provide the most valuable information about the future of the world, and help students (the community) in preparing essential needs to deal with change [1]. Jalaludin in this case argues that, education is basically a major factor in the lives of people who are able to move the changes and as an effort to meet the demands and needs of the times. Ibn Kathir explained that, the existence of education should be able to bring benefits and change to society [9].

The above findings also develop the mandate of Law No.20 of 2003 on the National Education System so that the inculcation of spiritual values with profane matters is simultaneously carried out in the education process in Indonesia.

This can be seen in article 3, which reads: National education functions to develop the ability and shape the character and civilization of a dignified nation in order to educate the life of the nation, aiming at developing the potential of students to become human beings of faith and devotion to God, Almighty, healthy, noble, healthy, knowledgeable, capable, creative, independent, and be a democratic and responsible citizen.

The above findings also support, strengthen and develop the theories put forward by strategic management experts as follows: 
According to J. Lee and D. Miller, educated, educated, knowledgeable people who have dynamic skills and attitudes will actually become the foundation to remain human resources who have endurance and competitive advantage, are able to exist and help companies achieve competitiveness strategic and will become increasingly large network of users who need these communities. Quality education as above according to J. Lee and D. Miller is called intangible resources. The more a resource cannot be observed (intangible), the more competitive advantage based on that resource has endurance [10].

The same thing was also said by Weston Agor's strategic management expert that, intuition is important to be used to make good strategic decisions. Intuition is especially useful for making decisions in very uncertain or little precedent situations. Intuition also helps when there is great pressure to do the right or have to choose from a number of alternatives that make sense [11].

The above findings also support, strengthen and develop theories put forward by psychologists such as Danah Zohar and Ian Mashall, where he both said that a person / community who has spiritual intelligence can improve the quality of life and existence becomes a spiritual capital ( spiritual capital) for an organization [12] .

Ary Ginanjar Agustian also said that, spiritual intelligence becomes a method, a clear and definite concept that fills the inner emptiness, soul and universal concepts that deliver a person / society to the title of satisfying himself and his fellow man [13].

With scientific evidence as above, developing spiritual education can truly be used as a solution in realizing Indonesian society ready to compete and win in the free market era.
B. Methods or methods that can be carried out to develop spiritual education in the free market era.

The ways / methods that can be done to develop the spiritual education include:

\section{Reconstructing the Curriculum by \\ Developing and Internalizing Spiritual \\ Values in Each Learning Material}

The findings in this study develop the theories put forward by existing spiritual education experts as follows:

According to Emha Ainun Najib thait, $f$ explored more thoroughly and thoroughly there is not a single branch of knowledge that is not related to the essence of God (spiritual) in it. So that after studying the profane knowledge it is expected that the students will become more capable in their faith and piety and be able to utilize the knowledge they have for the benefit / good of the wider community. Hujwiri said that the goal in pursuing his true knowledge after students gained their knowledge became makrifatullah (getting to know God) more closely [14]. Likewise, according to alGhozali, that, the purpose of the prosecutor of knowledge is to obtain useful knowledge in the afterlife and encourage obedience to Allah [15].

According to Ibn Jama'ah, the knowledge that has been obtained should be able to deliver someone to know God well. Ikhwan al-Shafa said that learning activities are nothing but the process of remembering. Before being sent down to earth, the soul knows everything (including God), then when it comes down to earth, it becomes forgotten, and learning to teach is nothing but actualizing potential things, giving birth to things that are buried deep within the soul.

This finding supports and strengthens and develops the theory put forward by Neil Postman that, in order for educational institutions to achieve benefits, they must have a goal so that their students become spiritualists. If educational institutions have a goal that their students become spiritualists 
(worship / obey and glorify the greatness of God) wherever they are, whether in the East or in the West, then there will be no school problems and certainly no school crisis. Conversely, if not, then the educational institution becomes meaningless [16].

For this reason, for Neil Postman, educational institutions so that they do not experience death, redefinition of school values (educational institutions) is very urgent to do immediately. Without a transcendent and noble goal, education in schools will surely reach the end (dead) and the faster it is to do with the transcendence and noble goals, the better. Through educational institutions such as these students / communities will find reasons for continuing education for themselves.

\section{Promoting Spiritual Education in} Developing Methods and Models as follows:

a. Provide training (workshops) to educators to be able to develop spiritual education

The above findings actually develop the mandate of government regulation No. 19 of 2005 concerning National Education Standards mentioned that the competency standards that must be possessed by a teacher are pedagogical competence, personal competence, competence, professional and social competence [17] .

The above findings also develop the mandate of the national education system law article 51 paragraph 1 states that the management of early childhood education, basic education and secondary education is carried out based on minimum service standards with the principles of school / madrasah based management.

According to Soetjipto and Raflis Kosasih that, teachers / lecturers as educators should also carry out activities of guidance, teaching and or exercise consciously to their students to achieve educational goals so that students become true and ideal human beings [18] .
The above findings also develop the theories put forward by scholars or experts in Islamic education as follows:

In the opinion of Ikhwan al-Shafa that educators are pillars of the educational process and place them in strategic positions, both theoretically-conceptually and practicallysociologically [15]. A student will find happiness if he finds compatibility with teachers who are intelligent, of good character, noble, sincere, lovers of knowledge and truth, and are not fanatically blind to certain traditions.

Asrori in this case also said that, the figure of teacher / lecturer / educator has a very large contribution to the success of learning, because the figure of teacher / lecturer / educator is truly able to help the development of students. In true learners there are talents, interests and abilities and other potentials that differ from one another, and it cannot develop without the help of a teacher [19]. Therefore teachers / lecturers / educators are required to have high creativity, professional, able to choose and apply an approach or methods of learning that are effective, creative and fun. This includes methods or ways to develop spiritual education.

Therefore, there is certainly a need for training of existing teachers / lecturers / educators to be able to carry out the spiritual development of education from the results of the existing curriculum reconstruction.

b. Bring in spiritual experts in order to put educators so that they are able to develop and internalize the spiritual values of education in every material in learning

For this reason the above findings actually develop the theory put forward by Mustafa Rahman that, God educates the Prophet, the Prophet educates the Friends, Friends educates the next generation as educators who continue until the end of time. This educational or scientific activity has a chain connection to God the creator of the universe. Herein lies the true glory of educator status [20]. 
For this reason, it is certainly necessary to bring in spiritual experts to guide the teachers / lecturers / educators in each education unit in order to establish the development and internalization of the spiritual values of education in every material in learning.

c. Enter into an agreement or MoU between the educational institution and educators in order to be willing to develop spiritual education while learning takes place

The above findings actually develop the mandate of Law No.20 of 2003 on the National Education System so that the inculcation of spiritual values with things that are profane at the same time should be carried out in the process of education in every education unit in Indonesia.

The above findings also develop the theory put forward by HM Arifin that, Islamic education must be able to lead students to become adult Muslims who fear, direct and guide growth, the development of the basic potential of students towards the maximum point. Essence of that potential refers to faith / belief (spiritual), science, morals, and experience. Schools as educational institutions must be able to make educational staff to be able to educate pious children individually and socially

The same thing was also said by Zakiyah Daradjat that, Islamic education must be able to turn students into human beings that are useful for themselves and their communities and are happy and fond of practicing, developing, Islamic teachings in dealing with God and fellow humans.

Achmadi also said that, students who are given education are expected to be able to preserve human values so that they become pious individually and socially and become more meaningful.

To achieve this goal, an agreement (MoU) between educational institutions and educators is needed to have the qualifications to be able to develop the spiritual education. And when it turns out the teacher is unable or unable to carry out the agreement, the educational institution has the right to replace it with educators who have the competence and qualifications that support the efforts to develop spiritual education.

\section{The scientific rational reasons for the spiritual development of education can be used as a solution to realize Indonesian society ready to compete in the free market arena}

As for various reasons logically scientific rationale that $\mathrm{m}$ engembang $\mathrm{k}$ 's spiritual education can serve as a solution to realize the people to victory in the era of free market that, in the application of spiritual development of education in each educational unit then the learners after gaining knowledge of the learning materials what alone in educational institutions they become not only intellectuals intelligent, but also emotionally intelligent and become spiritualists, close to Allah Almighty. This closeness to Allah SWT causes the outputs and outcomes of educational institutions to be an ideal society / human beings who always get guidance and help from Him to be able to compete and become the winner in competition in this free market era.

The findings in this study support and strengthen and develop the theory put forward by the following experts.

M. Ngalim Purwanto, an expert in educational psychology, said that, when viewed from an analysis of the system, it would seem to be one of the factors, namely external factors that also influence someone (the public) [21] who is ready to compete in the free market era.

Shah Wali Allah al-Dihlawi, Muhammad Makhdlori, Sahabuddin, Erbe Sentanu, Mechael J. Losier, Rhonda Byrne, Sandra Anne Taylor, Ahmad Sudirman Abbas, Moh. Sholeh, Wawan Susetya, Sudirman Tebba, Jamaluddin Ancok, Yusuf al-Qaradawi, Tobroni, Dan ah Zohar and Ian Mashall, Ary Ginanjar Agustian, Michal Levin in this regard said as follows: 
By practicing spirituality as expected it causes a person to become close to Allah [22]. Its closeness to Allah causes it to flow into itself energy (His Nur) [23] and moves the brain as the center of control. This brain works based on energy vibrations, and controls all activities. The vibrations that cause a person to act are actually sourced from His energy [24]. This is as explained by Erbe Sentanu that, "every human being has inherited in himself a tendency that makes his brain thirsty and is ready to accept the guidance of 'higher power', that is, the power of Almighty God".

This powerful energy, if empowered, will form a living magnet within the spiritualist, which in the concept of law of attraction can bring desire, and will transform into real experience according to its intensity. Because everything that is transmitted through thoughts, feelings, mental images, and speech will be brought back into life [25]. The same thing was also said by Rhonda Byrne, with the Divine energy that is in her, then someone / society that is spiritualist also becomes a magnet, so that something that is expected and desired is attracted towards it or vice versa it will become moving and activating towards something that is expected and desired [26].

Taylor also explained that, "Surely the science of personal (existing) energy and the mechanics of consciousness are the two most important natural factors that influence the outcome of one's goals. If someone is active in functioning of these elements, then he will see great changes begin to manifest in his life "[27].

Divine energy that is responded to by the brain and heart forms the potential for intelligence, and a spiritualist / society will become an increased level of consciousness [28]. With this increased intelligence and awareness potential, he has become able to move himself to carry out activities ready for competition in the free market era. This is because it is supported by moods, calm minds, and controlled emotions, so that they are eager (energized) to complete their tasks and responsibilities and are able to realize the goals of the organization where they are and work.

In addition, the effect of a person / community close to God makes the soul become calm, positive aura (energy) emanates from the culprit's soul. With a calm and positive soul that inspires inspiration and imagination with Divine guidance [29]. In addition, spiritualists also become cool to the eye, he said, weighted, good, quality; loss of feelings of pessimism, inferiority, inferiority, lack of weight and change to an attitude that is always optimistic, confident, brave without being arrogant and arrogant [30], increases the body's immune immunology and positive perception and motivation.

The transmission of positive energy from one's soul / spiritualist community is subsequently caused by the heart and soul being clean and pure, lust controlled so that daily activities in a week become controlled. Departing from this condition, when a person / community who works spiritually becomes protected from polluting stains [31]. At times like this spiritualists become pious [32] and have high morals [33], able to soften hearts and unite their subordinates (do teamwork), firm, willing to deliberate, not arbitrary, do not monopolize opinions [34] which causes all parties to become happy [30], and did not feel influenced to move and carry out Activities towards successful organizational goals.

This condition is what Danah Zohar and Ian Mashall say as a person / community who has spiritual intelligence that can improve the quality of life and its existence becomes a spiritual capital for an organization [35]. In this position spiritual intelligence becomes a method, a clear and definite concept that fills the emptiness of the mind, soul and universal concepts that deliver a person / society to the title of satisfying himself and his fellow man [13]. This is because a spirituality person / community understands the meaning and is able to portray love where it is [36]. 
Furthermore, with this spiritual intelligence, a person / community is able to make goodness, truth, beauty and compassion in existing organizations [35]. The implication of all this is that a spiritualist person / society will be able to influence others by inspiring without indoctrinating, awakening without hurting, awakening without coercion and inviting without commanding [34].

Thus it becomes clear that scientifically rational reasoning that developing spiritual education can be used as a solution for realizing society to win in the free market era.

The above findings in addition to supporting, reinforcing and developing theories and previous findings ter ter also reject the findings and theories put forward:

In this case Chablullah Wibisono said that, spiritual motivation (prayer, prayer, fasting) has a negative influence on employee performance [37].

\section{CONCLUSION}

The conclusion from this research is develop spiritual education can be used as a solution in bringing people to achieve victory in the era of free markets. The method can be done for the spiritual development of education in Indonesia are among the first by way of reconstruct curriculum to develop and internalize the spiritual values on any learning materials, both to do socialization spiritual development of education ie with give out training (workshops), mendatangkan spiritual experts, and melakukan agreement or MOU between the institutions pendidikan with educators.

\section{REFERENCES}

[1] Jalahudin, Filsfat Pendidikan Islam : Tela'ah Sejarah dan Pemikirannya, ( Jakarta: Kalam Mulia, 2011 ), h. 137

[2] Djoko Hartono, Pengembangan Life Skills dalam Pendidikan Islam (Penerbit: Media Qowiyul Amien - MQA Surabaya, 2008), 1-2.

[3] Lihat juga al-Qur'an, 7 (al-A'raf): 172,

[4] al-Qur'an, 2 (al-Baqorah): 30-34,
[5] al-Qur'an, 58 (al-Mujadalah): 11

[6] Djoko Hartono, Kekuatan Spiritual Para Pemimpin Sukses (Surabaya: MQA, 2011), 108, 114

[7] Tobroni, The Spriritual Leadership: Pengefektifan Organisasi Noble Industry Melalui Prinsip-Prinsip Spiritual Etis (Malang: UMM, 2005), 239-240.

[8] Muafi, "Pengaruh Motivasi Spiritual Karyawan Terhadap Kinerja Religius: Studi Empiris di Kawasan Industri Rungkut Surabaya (Jurnal Siasat Bisnis. Vol. 1, Nomor 8. Yogyakarta: Fakultas Ekonomi UII, 2003),

[9] Kathir, Ibnu, Mukhtasar Tafsir Ibn Kathir, Jilid 7, terj. Salim dan Said Bahreisy (Surabaya: Bina Ilmu, 2003).

[10] Lee, J. dan D. Miller, "People Matter; Godfrey \& Hill, The Problem of Unobservable, Strategic Management Journal, 20, (1999).

[11] Agor, Weston, "How Top Executive Use Their Intuition to Make Important Decisions", Business Harizons, 29, No.1 (Januari-February 1986), 6. Lihat juga, Andrew Campbell, "Brief Case: Strategy and Intuition-A Conversation with Henry Mintzberg", Long Range Planning, 24, No. 2 (April 1991).

[12] Zohar, Danah dan Mashall, Ian, Spiritual Capital: Memberdayakan SQ di Dunia Bisnis, terj. Helmi Mustofa (Bandung: Mizan, 2005).

[13] Agustian, Ary Ginanjar, Emotional Spiritual Quotient,the Way 165, Rahasia Sukses Membangun Kecerdasan Emosi \& Spiritual, Jilid 1 Edisi Revisi (Jakarta: PT Arga Tilanta, 2001).

[14] Ali Ibn Utsman al-Hujwiri, The Kasyf alMahjub: The Oldest Persian Treatise on Sufism, Terj. Suwardjo Muthary dan Abdul Hadi W.M (Bandung: Mizan, 1995).

[15] Ridla, Jawwad Muhammad, al-Fikr alTarbawiyy al-Islamiyyu Muqaddimat fi Ushulih al-Ijtima'iyyati wa al-'Aqlaniyyat, Terj. Mahmud Arif (Yogyakarta: PT. Tiara Wacana, 2002), 60.

[16] Postman, Neil, Matinya Pendidikan: Redefinisi Nilai-Nilai Sekolah, Terj. Siti Farida (Yogyakarta: Jendela, 2001).

[17] Himpunan Perundang-Undangan Republik Indonesia, Tentang Badan Pendidikan Nasional (Bandung: Media Purnama, 2009). 
[18] Soetjipto dan Kosasih, Raflis, Profesi Keguruan (Jakarta: Rineka Cipta, 2009).

[19] Asrori, “Inovasi Pembelajaran Quantum", dalam Inovasi Pendidikan dan Pembelajaran, Merajut Asa Pendidikan Islam di Tengah Kontestasi dalam Sistem Pendidikan Nasional, Ed. Abd. Haris dan Sholehuddin (Surabaya: Imtiyaz, 2014).

[20] Rahman, Musthafa, Humanisasi Pendidikan Islam, Plus-minus Sistem Pendidikan Pesantren (Semarang: Walisongo Press, 2011).

[21] Purwanto, M. Ngalim, Psikologi Pendidikan (Bandung: Remaja Rosdakarya, 1991).

[22] Shah Wali Allah al-Dihlawi, Hujjah Allah alBalighah: Argumen Puncak Allah, Kearifan dan Dimensi Batin Syariat, terj. Nuruddin Hidayat \& C. Romli Bihar Anwar (Jakarta: Serambi Ilmu Semesta, 2005).

[23] Makhdlori, Muhammad, Menyingkap Mukjizat Shalat Dhuha (Yogyakarta: Diva Press, 2008).

[24] Sahabuddin, Nur Muhammad Pintu Menuju Allah (Jakarta: Logos Wacana Ilmu, 2002).

[25] Losier, Michael J., Law of Attraction: Mengungkap Rahasia Kehidupan, terj. Arif Subiyanto (Jakarta: Ufuk Press, 2008).

[26] Rhonda Byrne, The Secret: Rahasia, terj. Susi Purwoko (Jakarta: Gramedia Pustaka Utama, 2008).

[27] Taylor, Sandra Anne, Quantum Success: Lompatan Dahsyat Syahidin, et.al., Pendidikan Agama Islam Untuk Perguruan Tinggi (Surabaya: Unesa University Press, 2014).

[28] Sentanu, Erbe, Quantum Ikhlas: Teknologi Aktivasi Kekuatan Hati (Jakarta: Elex Media Komputindo, 2007).

[29] Abbas, Ahmad Sudirman, The Power of Tahajud: Cara dan Kisah Nyata Orang-orang Sukses (Jakarta: Qurtum Media, 2008).

[30] Sholeh, Moh., Terapi Salat Tahajud Menyembuhkan Berbagai Penyakit (Jakarta: Hikmah, 2007).

[31] Susetya, Wawan, Fungsi-Fungsi Terapi Psikologi \& Medis di Balik Puasa Senin Kamis (Yogyakarta: Diva Press, 2008).

[32] Tebba, Sudirman, Tasawuf Positif (Jakarta: Prenada Media, 2003), 150-151, Lihat juga Jamaluddin Ancok, Psikologi Islam : Solusi Islam atas Problem-Problem Psikologi (Yogyakarta: Pustaka Pelajar, 1994).
[33] Qaradawi, al Yusuf -, Ibadah Dalam Islam, terj. Umar Fanani (Surabaya: Bina Ilmu, 1998).

[34] Tobroni, The Spriritual Leadership: Pengefektifan Organisasi Noble Industry Melalui Prinsip-Prinsip Spiritual Etis (Malang: UMM, 2005).

[35] Zohar, Danah dan Mashall, Ian, Spiritual Capital: Memberdayakan SQ di Dunia Bisnis, terj. Helmi Mustofa (Bandung: Mizan, 2005).

[36] Levin, Michal, Spiritual Intelligence: Membangkitkan Kekuatan Spiritual dan IntuisiAnda, terj. Andri Kristiawan (Jakarta: Gramedia Pustaka Utama, 2005).

[37] Wibisono, Chablullah. "Pengaruh Spiritual terhadap Kinerja Karyawan Sub Sektor Industri Manufaktur di Batamindo Batam", (Ringkasan Disertasi, Universitas Airlangga, 2002.

[38] Simuh. Islam dan Pergumulan Budaya Jawa. Jakarta: Teraju, 2003. 